\title{
January 27 Highlight and Commentary
}

\section{Features of fluctuations that distinguish DLB from AD and normal aging}

Ferman et al. administered a questionnaire to informants of 200 normal elderly, 70 dementia with Lewy bodies (DLB), and 70 Alzheimer disease (AD) patients. Disturbed arousal and disorganized speech are specific features of DLB fluctuations that reliably distinguish DLB from $\mathrm{AD}$ and normal aging. Studies with a separate sample established test-retest reliability.

see page 181

Commentary by Douglas Galasko, MD

Dementia with Lewy bodies (DLB) is often difficult to distinguish from Alzheimer disease (AD). The core clinical features of DLB-fluctuation of cognition or awareness, spontaneous parkinsonism, and hallucinationshave relatively low diagnostic sensitivity. The weakest link is the lack of a standardized approach to detect and describe fluctuation. Ferman et al. took a step to remedy this by developing a series of questions about sleep, alertness, and cognition and administering them to informants of patients with clinical diagnoses of $\mathrm{DLB}$ or $\mathrm{AD}$ and to elderly controls. ${ }^{1}$ Four symptoms were more common in $\mathrm{DLB}$ than $\mathrm{AD}$ : day- time drowsiness even after enough sleep the night before, sleeping 2 hours or more during the day, staring into space, and disorganized or unclear flow of ideas. Three or four of these symptoms were reported in $63 \%$ of patients with DLB, significantly higher than in $\mathrm{AD}(13 \%)$, a finding that was validated in a second set of patients. Interestingly, informants did not notice fluctuating cognitive abilities in DLB, in contrast to psychometric studies, which have reported findings consistent with short-term variation in attention in these patients. The study suggests that it is more profitable to solicit features of daytime sleepiness, impaired at- tention and concentration, and confusion from informants of patients with dementia than to ask them to rate variations in cognitive performance. Recent neuropathology studies have highlighted early involvement of areas such as the brainstem reticular activating system and locus ceruleus in DLB, which could provide a substrate for this delirium-like picture.

\section{Reference}

1. Ferman TJ, Smith GE, Boeve BF, et al. DLB fluctuations: Specific features that reliably differentiate DLB from $\mathrm{AD}$ and normal aging. Neurology $2004 ; 62: 181-187$.

see page 181 


\title{
Neurology
}

\author{
January 27 Highlight and Commentary \\ Neurology 2004;62;165 \\ DOI 10.1212/WNL.62.2.165
}

This information is current as of January 26, 2004

\section{Updated Information \&} Services

References

Permissions \& Licensing

Reprints including high resolution figures, can be found at: http://n.neurology.org/content/62/2/165.full

This article cites 1 articles, 1 of which you can access for free at: http://n.neurology.org/content/62/2/165.full\#ref-list-1

Information about reproducing this article in parts (figures,tables) or in its entirety can be found online at:

http://www.neurology.org/about/about_the_journal\#permissions

Information about ordering reprints can be found online:

http://n.neurology.org/subscribers/advertise

Neurology ${ }^{\circledR}$ is the official journal of the American Academy of Neurology. Published continuously since 1951, it is now a weekly with 48 issues per year. Copyright . All rights reserved. Print ISSN: 0028-3878. Online ISSN: 1526-632X.

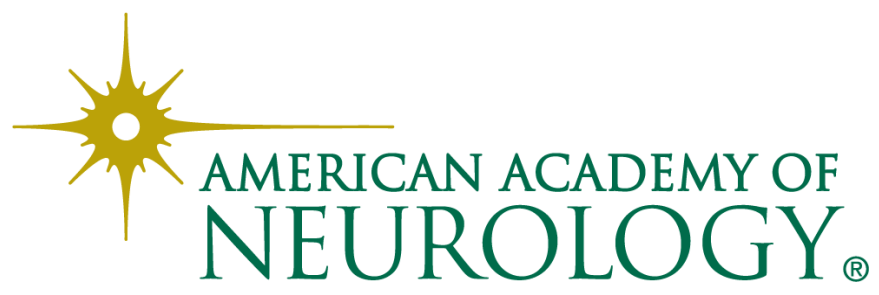

